\title{
変形性膝関節症のための膝装具の歩行時の変形評価に関する研究
}

\section{The Study of the Deformation Evaluation During Gait of the Knee-Brace for Knee-Osteoarthritis}

\author{
嶺也守寬(正会員) \\ Yasuhiro Mine
}

\begin{abstract}
The purpose of this study establishes an evaluation of correlation between the gait and the structure of the knee- brace (CB-brace) for K-OA. The optical 3D motion capture analysis system was used for gait analysis. In advance, we confirmed the fit of the knee brace and the ratio of the medial compartment by two measurement methods. One confirmed the ratio of the medial compartment of the knee by measuring the gap between the center of the knee joint and Mikulicz line while another carried out gait analysis without wearing and while wearing knee-brace. The extent of the knee pain of the each subject can be objectively evaluated by referring to the visual analogue scale (VAS) for each trial. We measured the structure characteristic of the knee-brace attached 8makers on arm support during gait. The results showed (1) The angle change amount of each arm. (2) The distance between the top of each arm and the joint. (3) The posture change of the knee brace by the degree of the rotation angle of the X, Y, Z axis by the orthosis coordinate system. In conclusion, we evaluated the correlation of the knee-orthosis structure during gait.
\end{abstract}

\section{Key Words}

Knee-Osteoarthritis, CB-Brace, Gait analysis, Orthosis structure, Rehabilitation

\section{1. はじめに}

変形性膝関節症 (Knee-Osteoarthritis 以下, 膝 $\mathrm{OA}$ ) は, 加齢や肥満 などの影響により膝関節部の軟骨や半月板がすり減ることによって膝 関節裂隙の狭小化が起こり, 大腿骨と脛骨の接触が膝関節部の疼痛 を引き起こすことが判っている. ${ }^{1)}$ 膝 OAのグレード分類ししては, X線 画像による Kellgren-Lawrence Grading Scale ${ }^{2)}$ が用いられるが, 一般的 にグレードが高くなり重症化するほど, 膝関節が内反を呈する. 厚生 労働省の調査 ${ }^{3)}$ では, 関節症と言われる推定患者総数は 125 万人以 上存在し, 年齢的な分布を見ても 65 歳以上の患者数が圧倒的に多い ことが示されている. また, 男女比においては男性の患者数は 29 万人 に対し女性の患者数は 96 万人と女性の方が多いことが判る. 一方, 吉 村ら ${ }^{4}$ が調査した結果から推察したX線画像上での膝 OA の患者数は 男性が 840 万人, 女性が 1,540 万人であり, 総数としては 2,400 万人と 言われており, 潜在的な関節症を持つ患者を含めたとしても相当な数

2016 年 10 月 12 日受付

2017 年 2 月 16 日掲載決定

東洋大学 ライフデザイン学部 人間環境デザイン学科

テ351-8510 埼玉県朝霞市岡 48-1

Department of Human Environment Design, Faculty of human Life

Design, Toyo University, 48-1 oka, asaka city, Saitama, 351-8510
である. 高齢者にとって歩くことは QOL (Quality of Life)を維持向上す るためにも関節症の疼痛を軽減することは重要なことである. 一般に 膝OA の治療方法としては, 大きく分けて保存療法と手術療法の2つ 5 ) がある. 保存療法には, 理学療法, 物理療法, 薬物療法, 装具療法な ごがあり,これらの組み合わせで治療が行われる.この中の装具療法 としては, 膝装具を装着することで膝の内反を矯正し, 膝の疼痛が軽 減されることでリハビリに対する意欲が向上し, 理学療法を受けながら 膝周りの筋力を付け回復へと向からことを目標としている. 膝 OA の歩 容に関寸る研究では, 飯田ら ${ }^{6)}$ が行った立脚初期と中期における体幹 と骨盤の回旋や側屈運動との関係を明らかにしたものや田中ら ${ }^{7)}$ が行 った OA 側と非 OA 側との機能の差を明らかにしたものがある.これら は, 膝 OA の病態における歩容について分析したものである. また, 膝 OA の特徴の1つとして, Fig.1に示寸 Lateral thrust が見られるが, これは内反の影響によるアライメントの異常から立脚初期の踵接地か ら荷重応答の範囲内で, 床反力の内反モーメントによる横ぶれとも言 われる瞬間的な内反運動が出現する.これを繰り返すことで膝 OA の 増悪に関与していることが, Chang A $~^{8)}$, Grace H. Lo $ら^{9)}$, や Kuroyanagi Y ${ }^{10)}$ が報告されている. 


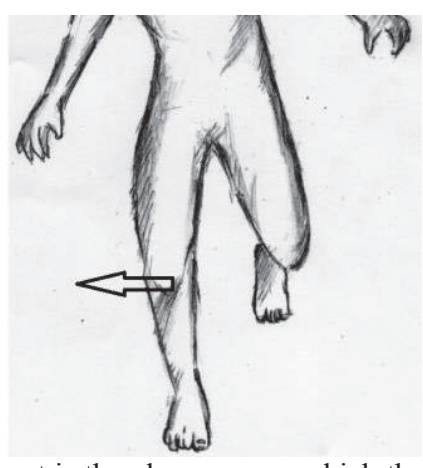

Fig.1 Lateral thrust is the phenomenon which the knee joint move outside suddenly from initial contact to loading response.

膝 OA に対する装具としては, 外側楔形足底板があるが, 清水 $ら^{11)}$ は, 足底板を使用して健常者と膝 $\mathrm{OA}$ 患者の歩容の比較から, その有効性について評価した報告があり, また, 小村ら ${ }^{12)}$ は, 膝 OA の特徵である Lateral thrustを定量的に評価するために, 若年 健常者, 高齢健常者, 膝 $\mathrm{OA}$ 患者の歩行分析を行い, その際に 足底板を用いた比較評価を行っている. 膝装具を用いた歩行分 析では, 岡本ら ${ }^{13)}$ が行った軟性装具を装着したときの Lateral thrust が有意に減少することが報告されている.

膝装具の構造が果たす役割としては, 膝の内反モーメントを矯 正し立脚初期の Lateral thrust による膝関節の不安定性を減少さ せる作用があるとされている. これは歩行中における装具の構造 と膝関節周りとの動きに関して, 常に作用反作用の関係が成り立 つと考えられる. しかし, 従来の研究では, 膝関節装具を装着す ることによってどう歩容改善されたかに着目する研究報告が多く, 歩容改善の元となる歩行時における装具の構造的な側面から見 た研究は報告されていない. 本研究では, 使用する実験用装具 が被験者に適応をすることを確認した上で, 歩行中の膝装具の構 造がどの様に変形するかの検証を行うことを目的とする.

\section{2. 計測方法}

\section{1 対象とした膝装具}

今回, 対象とした装具は, Fig. 2 に示寸金属支柱型の膝装具 (佐喜眞義肢製 $\mathrm{CB}$ ブレース)を使用した. この装具の仕様として は, アルミ製の 4 つ支柱に対して継手部を中心に, 膝背面側にセ ンターブリッジを設けることによって装具全体の剛性を保持できる ことが特徴である. また, 装具の構造としては, 大腿部と下腿部の 3 点で支持することにより膝の内反モーメントを矯正し, 疼痛を減 少させる作用がある.

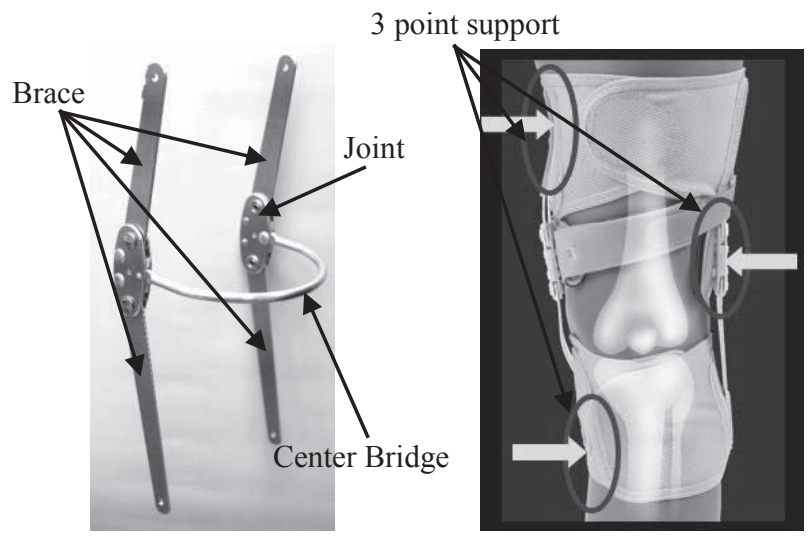

Fig.2 The Knee-brace used for this study.

\section{2 計測システム}

今回の歩行計測では, 光学式 3 次元動作分析装置 (VICON MX:カメラ 24 台)を使用した. また, 床反力計のない広大な計測 システムのため, 立脚・遊脚を判別するための LED 発光マーカを 制作した. Fig.3, Fig.4 に示す仕組みは, 足袋のつま先と踵部に 圧力センサーを取り付け, センサーが感知したときにカメラのスト ロボの赤色光と同波長 $(120 \mathrm{~Hz})$ の赤色 LED を発光させカメラに認 識させる仕組みとなっている. マーカは, 肩峰, 肘関節, 手関節, 股関節, 膝関節, 足関節, 第 5 中足骨の 14 点と LED 発光マーカ を上後腸骨棘の両側に取り付けた. また, 歩行中の装具の構造 的な変形を検証するために, 装具の内側と外側の支柱に合計8 点のマーカを取り付けた.

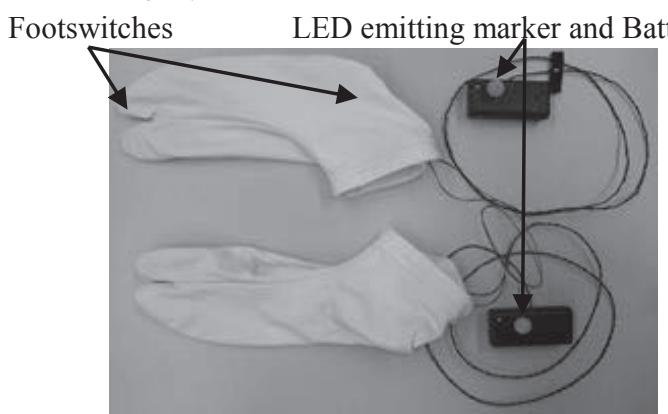

Fig.3 The LED emitting marker for distinguish between stance phase and swing phase.

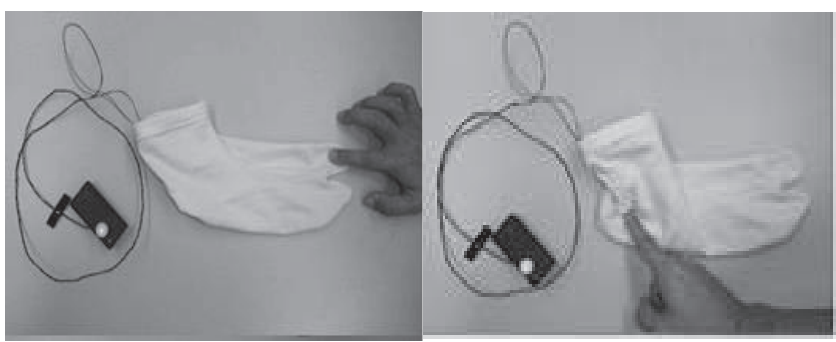

Fig.4 Footswitches of the heel and the toe.

\section{3 事前検証}

装具構造と歩容の関係を検証する前に, 被験者の膝の内反度 合いを確認するためにミクリッツ線(Mechanical axis $\left.{ }^{14)}\right)$ の検証を 行った. また, 使用装具の適応を確認するために歩行速度とVAS (Visual Analog Scale:0〜100mm)の比較検証を行った. 今回の 検証で使用した VAS は, 歩行路を歩き終わった地点に Fig.5 に 示す質問票を置き, 歩行した後の膝の痛みの程度を数值化する ものである. 主観的ではあるが痛みの程度を表すには広く用いら れている手法である.

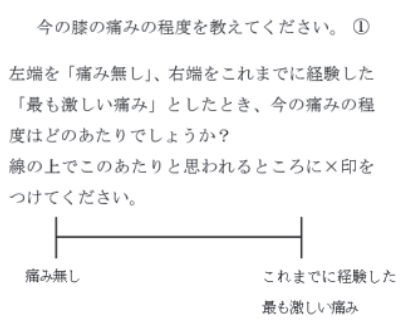

Fig.5 Visual Analog Scale used to measure pain level of the knee of subject.

被験者は, 罹患側に膝の手術歴がなく医師より変形性膝関節 症と診断された Kellgren-Lawrence 分類のグレード $2 \sim 3$ までを 
対象とし, 被験者との面談では, 今回の実験の趣旨と内容を説明 した上でインフォームドコンセントを得た後, 日本整形外科学会が 提唱している変形性膝関節症患者機能評価尺度 (JKOM $\left.{ }^{15}\right)$ : 100 点満点)を使用して日常での膝の状態を確認した. JKOM は, 主に変形性膝関節症の方を対象とした評価手法であり, 痛みの 程度を表すVAS と25問ある設問に回答して評価する. 各設問は, 最も軽症が 0 , 最も重症が 4 とした 5 段階で点数化され, その総 点によって重症度を判断している.

なお, 本研究は, 東洋大学ライフデザイン学部倫理委員会の 承認(LH27-012S)を得ている.

\subsection{1 ミクリッツ線により内反度合いの検証}

ミクリッツ線は, Fig.6 に示す通り, 両側股関節マーカを結ぶ線で 股関節マーカ位置から $21 \%$ 内挿した点と足関節内果マーカと外 果マーカを結ぶ線上の中心の点とを結ぶ線のことを指す.このミ クリッツ線と膝関節内果マーカと外果マーカとの中心点の位置関 係により内反の度合いを確認した. ここでは, 静止立位の状態で3 試行を行い, 平均值を算出している.

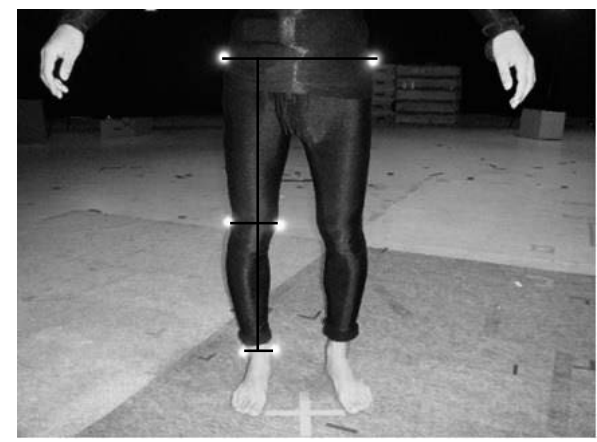

Fig.6 Mikulicz line

\subsection{2 実験用装具の適応に関する検証}

今回の実験に使用した膝装具が被験者に適応しているかを事 前に確認した. 条件としては, 装具を装着していない状態と日頃 から使用しているご自身の装具を装着した状態と実験用装具を装 着した状態の3条件とした. 被験者が日頃使われている装具は, カーボン製を使用されているなど材質の違いが見られるため, 装 具タイプが同種のもので材質を統一して実験用装具とした. それ らの各条件で $10 \mathrm{~m}$ の歩行路を自由歩行で6試行行ったときの体 重心(COG: Center of Gravity)か圤算出した歩行スピードの平均 值及び試行毎のVAS の平均值を比較し, 装具装着したことによっ て膝の疼痛が軽減した場合を適応した装具であると判断してい る.

\subsection{3 対象とした被験者}

上記 2.3 .1 及び 2.3 .2 の事前検証から対象とした 3 名の被験者 情報を以下に示す。

a) 被験者 $\mathrm{A}$

年齢: 57 歳, 性別:女性, 身長: $153 \mathrm{~cm}$, 体重: $61.9 \mathrm{~kg}$, 罹患 側: 右膝 (約 10 年前加), 手術歴:なし, 装具: 膝装具使用, ミク リッツ線により内反度合い:右 $21.3 \pm 1.2 \mathrm{~mm}$ 左 $19.4 \pm 1.0 \mathrm{~mm}, \mathrm{~J}$ $\mathrm{KOM}: 38$ 点, VAS:21 点

膝装具の適応検証 (Table 1)

Table 1 VAS score and gait speed of subject A

\begin{tabular}{|l|c|c|}
\hline & VAS score & Gait speed $(\mathrm{km} / \mathrm{h})$ \\
\hline Without orthosis & $39.7 \pm 10.2$ & $3.2 \pm 0.14$ \\
\hline Daily used orthosis & $15.7 \pm 1.9$ & $3.2 \pm 0.15$ \\
\hline Experiment orthosis & $20.2 \pm 5.7$ & $3.3 \pm 0.10$ \\
\hline
\end{tabular}

b) 被験者B

年齢: 78 歳, 性別: 男性, 身長: $157 \mathrm{~cm}$, 体重: $65 \mathrm{~kg}$, 罹患側: 左膝 (約 10 年前㘦), 手術歴:なし, 装具:膝装具使用, ミクリッ ツ線により内反度合い: 右 $-0.4 \pm 1.8 \mathrm{~mm}$ 左 $39.2 \pm 2.0 \mathrm{~mm}$, JKOM:42 点, VAS: 56 点

膝装具の適応検証 (Table 2)

Table 2 VAS score and gait speed of subject B

\begin{tabular}{|l|c|c|}
\hline & VAS score & Gait speed $(\mathrm{km} / \mathrm{h})$ \\
\hline Without orthosis & $15.8 \pm 6.9$ & $3.2 \pm 0.17$ \\
\hline Daily used orthosis & $3.2 \pm 1.7$ & $3.9 \pm 0.36$ \\
\hline Experiment orthosis & $6.5 \pm 3.1$ & $3.4 \pm 0.30$ \\
\hline
\end{tabular}

c) 被験者 C

年齢: 80 歳, 性別: 男性, 身長: $156 \mathrm{~cm}$, 体重: $65 \mathrm{~kg}$, 罹患側: 右膝, 手術歴: 左膝人工関節, 装具: 膝装具使用, ミクリッツ線に より内反度合い:右 $7.3 \pm 0.2 \mathrm{~mm}$ 左 $-1.2 \pm 0.8 \mathrm{~mm}, \mathrm{JKOM}: 53$ 点, VAS: 52 点

膝装具の適応検証 (Table 3)

Table 3 VAS score and gait speed of subject C

\begin{tabular}{|l|c|c|}
\hline & VAS score & Gait speed $(\mathrm{km} / \mathrm{h})$ \\
\hline Without orthosis & $30.5 \pm 15.1$ & $2.4 \pm 0.18$ \\
\hline Daily used orthosis & $1.5 \pm 0.5$ & $3.5 \pm 0.35$ \\
\hline Experiment orthosis & $1.3 \pm 0.5$ & $2.9 \pm 0.27$ \\
\hline
\end{tabular}

\section{4 歩行中の装具構造変形の計測方法}

膝 $\mathrm{OA}$ 用装具を装着した際の, 歩行中の装具構造の変形につ いて検証を行った. 実験方法は, 装具支柱の外側に 4 点, 内側に 4 点のマーカを取り付け, 更に, 足関節, 第 5 中足骨, LED 発光 マーカを上後腸骨棘の両側に取り付け, 立脚遊脚の判別を行っ た. 被験者には, 2.3.2 に示寸条件と同様に $10 \mathrm{~m}$ の歩行路を自由 歩行で6試行行った.
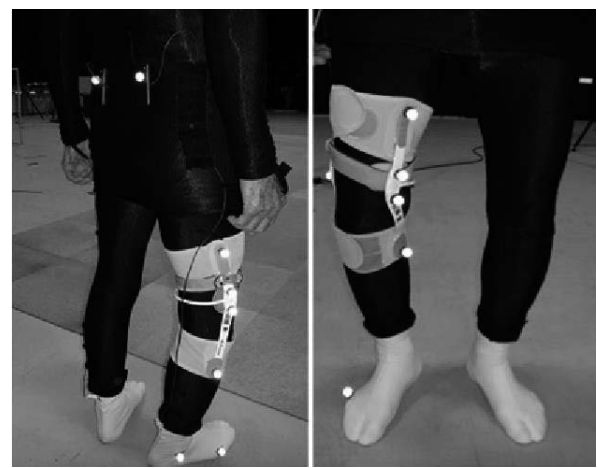

Fig.7 The position of marker attached for structure analysis of knee-orthosis.

歩行中の装具の構造変形に関する評価ポイントは, Fig.8, Fig.9 に示す装具支柱や継手に付けられた8個のマーカから得ら れる計測データであり, 以下の3つの検証を行った.

(1)各アーム部の角度変化.

(2)下腿部及び大腿部のアーム部先端と継手との距離.

(3)継手間の中心位置に仮想点を作成し, それを装具座標原点と したときの装具の姿勢について, 矢状軸をY 軸, 前額軸をX軸, 垂直軸をZ軸とした各軸周りの回転角度変化で確認した。

なお, 装具の構造的な解析にはVENUS3D を使用した. 得られ たデータは移動平均処理を行い, 1歩行周期を正規化している. 

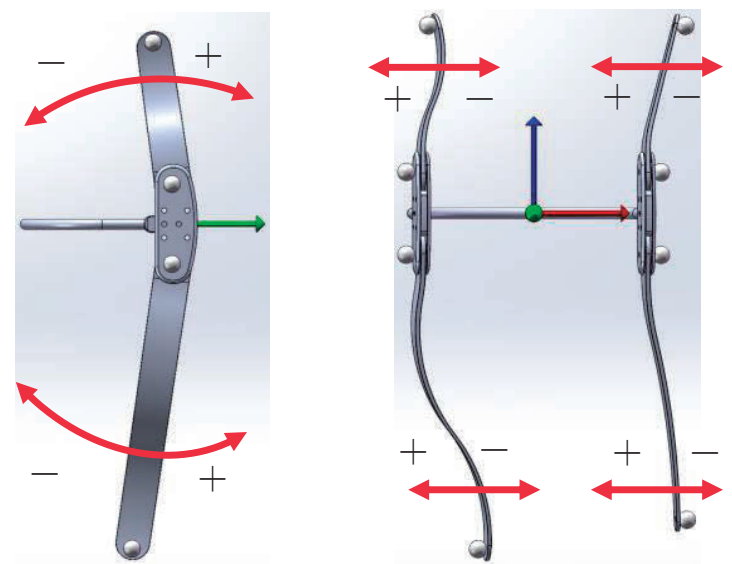

Fig.8 The evaluation point of the knee-orthosis structure.

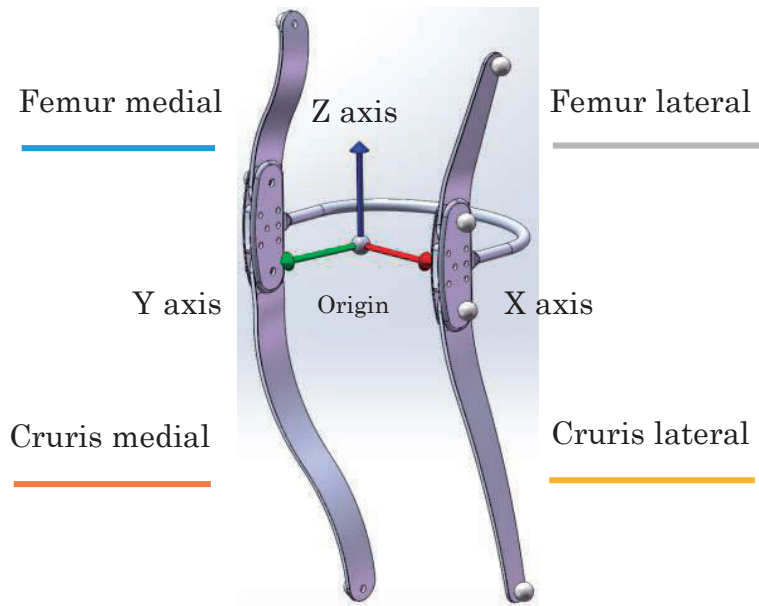

Fig.9 The evaluation of the orthosis posture by the orthosis coordinate system.

\section{3. 結果}

\section{1 継手を回転中心とした角度変化量}

Fig.10 から Fig.12 は, 各被験者の大腿部外側アーム部 (Femur lateral), 下腿部外側アーム部(Cruris lateral), 大腿部内側アーム 部(Femur medial), 下腿部内側アーム部 (Cruris medial)の継手を 中心とした角度変化量を示す. 角度のプラス側とマイナス側は Fig.8 に示す. 計測は装具を装着して静止立位からスタートし, 計 測空間の中ほど通過したときの踵接地からの1歩行周期をサンプ リングしている.

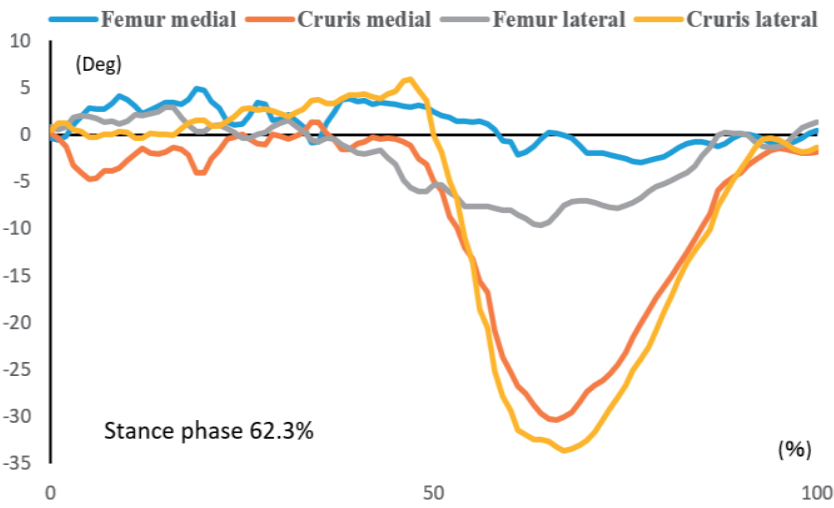

Fig.10 The angle of each support arm of subject A.

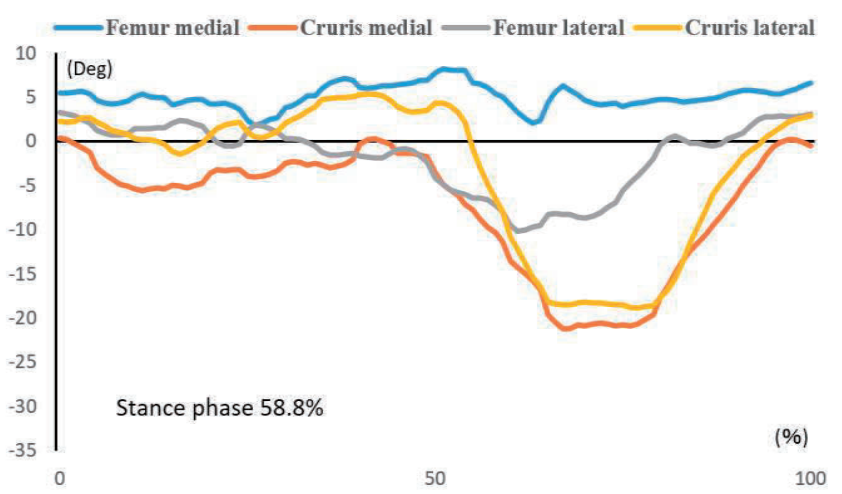

Fig.11 The angle of each support arm of subject B.

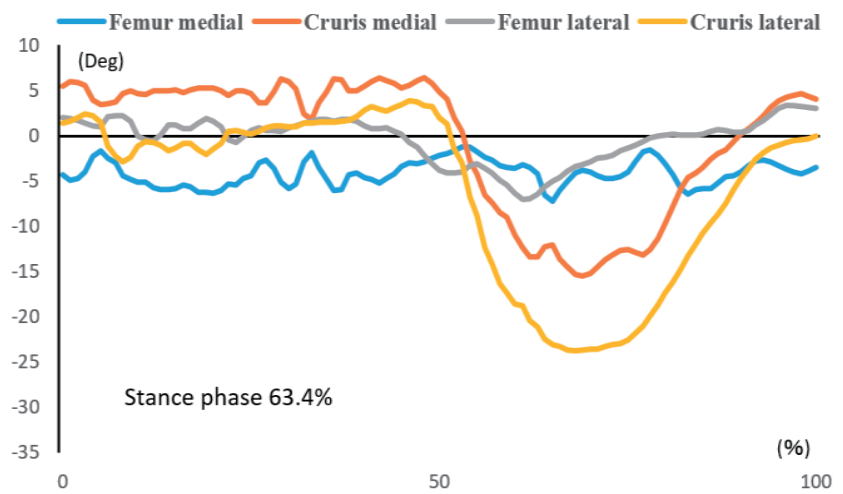

Fig.12 The angle of each support arm of subject C.

\section{2 アーム先端部と継手との距離変化量}

Fig.13 から Fig.15 は, 各被験者の大腿部内側アーム部 (Femur medial)の先端, 大腿部外側アーム部(Femur lateral)の先端, 下 腿部内側アーム部 (Cruris medial) の先端, 下腿部外側アーム部 (Cruris lateral)の先端と継手との前額軸X軸方向の距離変化量を 示す. 距離変化量のプラス側とマイナス側は Fig.8 に示す. 計測 は装具を装着して静止立位からスタートし, 計測空間の中ほど通 過したときの踵接地からの1歩行周期をサンプリングしている.

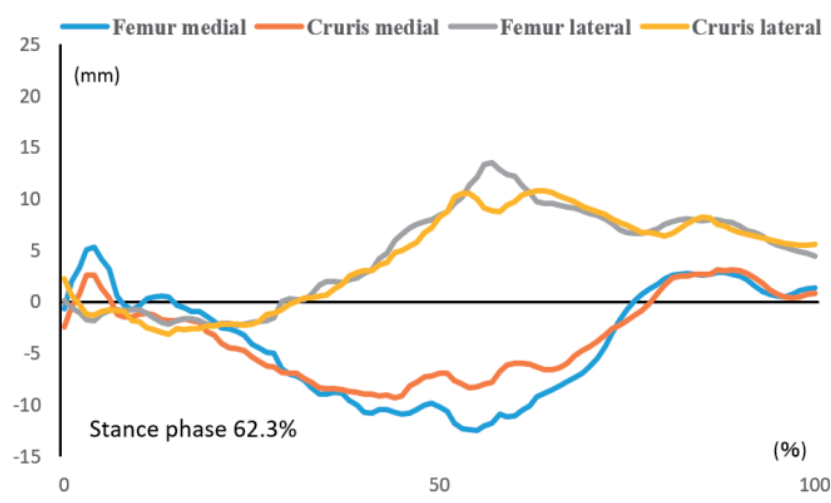

Fig.13 The distance between the joint and the top of the support arm of subject A. 


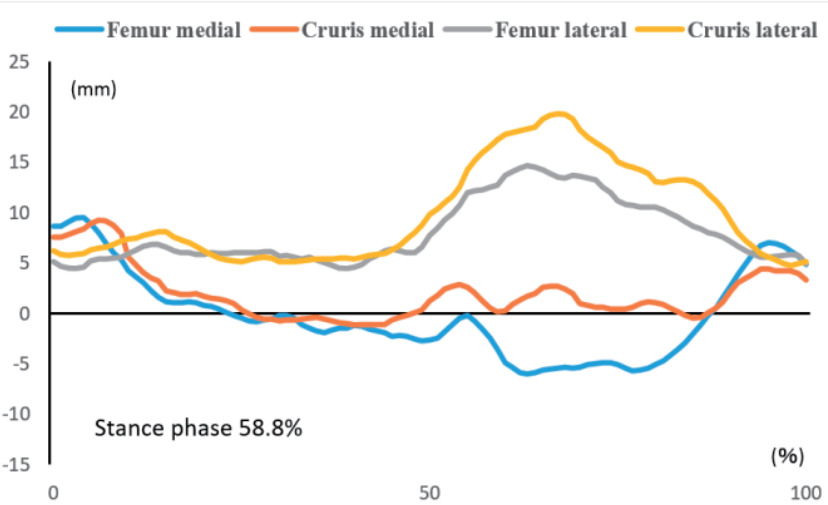

Fig.14 The distance between the joint and the top of the support arm of subject B.

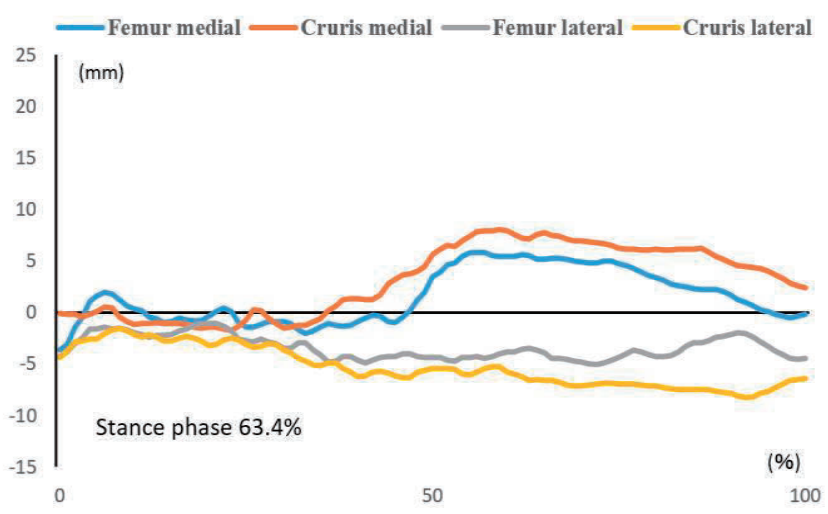

Fig.15 The distance between the joint and the top of the support arm of subject C.

\section{3 継手間を膝装具の装具座標系とした角度変化量の考察}

今回計測に使用した装具の構造としては, 左右の継手から装 具背面にかけて Center bridge と呼ばれる金属の支柱が入ってお り, 装具全体の剛性を保っている. この左右の継手の4つの回転 中心から合成した中心点を装具原点とし, 歩行中の装具の姿勢 変化を角度変化量で示した. 計測は装具を装着して静止立位か らスタートし, 計測空間の中ほど通過したときの踵接地からの1歩 行周期をサンプリングしている. Fig. 16 から Fig. 18 に示寸角度変 化量は, 計測座標系を基準とした装具座標系の角度差を装具姿 位としている.

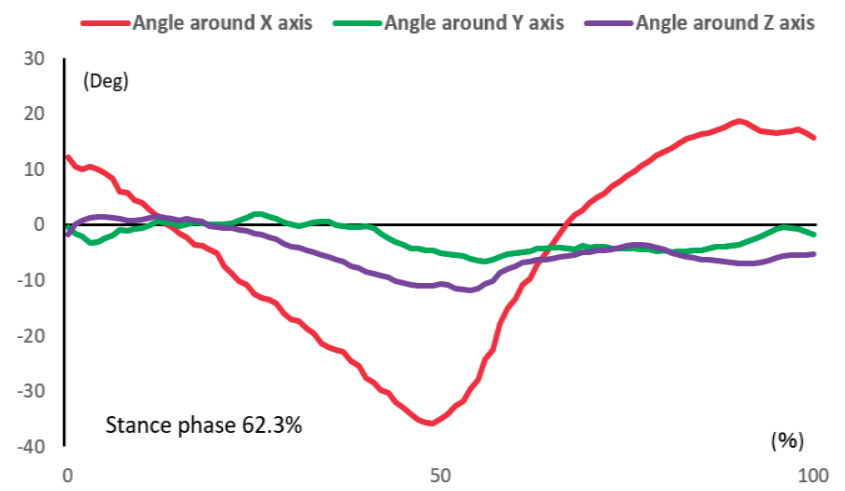

Fig.16 The attitude of orthosis by the orthosis coordinate system of subject A.

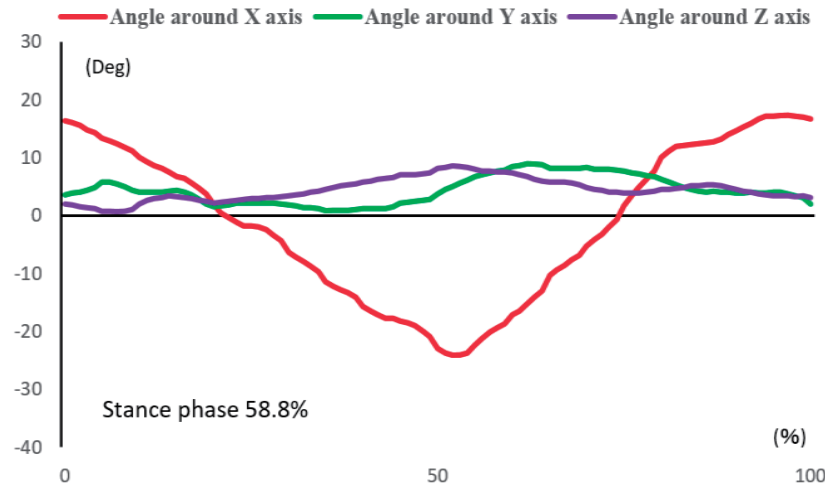

Fig.17 The attitude of orthosis by the orthosis coordinate system of subject $B$.

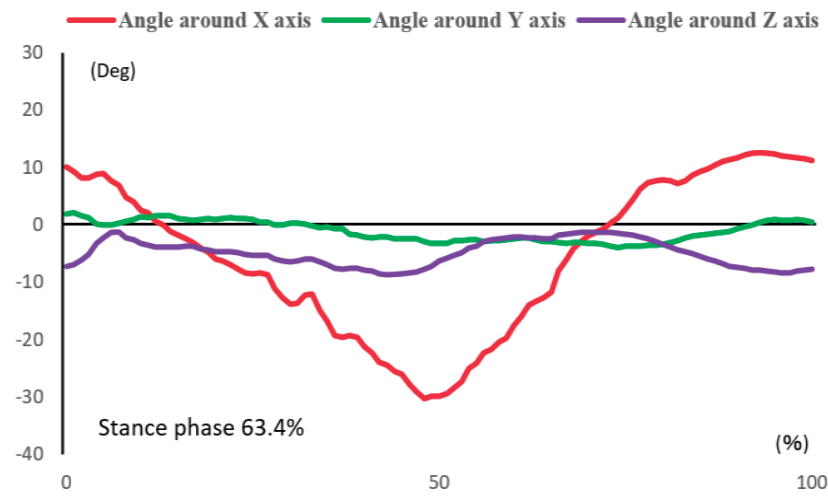

Fig.18 The attitude of orthosis by the orthosis coordinate system of subject $\mathrm{C}$.

\section{4. 考察}

\section{1 継手を回転中心とした角度変化量の考察}

被験者 $\mathrm{A}$ は, 各試行の歩行スピードは変わらないものの装具を 装着することによって膝の痛みを緩和していることがVAS によって 確認できた. Fig.10 に示す大腿部及び下腿部のアーム部の継手 を中心とした角度変化量では, 大腿部内側のアーム部の角度変 化量は大幅な変動は少ないが, 大腿部外側アーム部は, 最大約 $10^{\circ}$ の角度で変動していることが判る. また, 下腿部外側アーム 部に関しては, 立脚後期のピーク時から遊脚中期のピーク時まで 約 $40^{\circ}$ の角度で変動している. 下腿部の内側アーム部と外側ア 一ム部の角度差及び大腿部の内側アーム部と外側アーム部の角 度差の変化は, 脚部の外内転の影響によるものと考えられる. 被 験者Bは, ミクリッツ線の内反度合いから左膝が右膝に比べて極 端に内反傾向にあることが判る. VAS の結果から装具を装着する と膝の痛みは緩和されているが, 被験者 $\mathrm{A}$ と同様にご自分の装具 の方が慣れている様である. Fig.11 のアーム部角度の変化量で は, 下腿部の遊脚中期に他の被験者には見られない特徵的なピ 一クが見られる.これは下腿伸展時の膝の疼痛が関係しているも のと思われる. また, 大腿部外側アーム部の角度変化量が他の被 験者と同等なのに対して下腿部アーム部の角度変化量が約 2 $0^{\circ}$ と低い值なのは膝伸展が十分に出来ていないことが言える. 被験者 Cは, Fig.12 に示される通り, 立脚期が比較的長くとられて いるが，遊脚期は短く下腿伸展角度があまり大きくない. 左膝を 人工関節に変えた後, 歩行バランスの影響からか右膝に疼痛が ある. 装具を装着することで疼痛が軽減されるが, 実験用装具で 
は日頃使用されている装具より不安感があるためか歩行スピード が下がっている. 遊脚における下腿内側アーム部と下腿外側アー ム部の角度差は, ピークで約 $8^{\circ}$ の差があり解析動画からも外旋 していることが判った。

\section{2 アーム先端部と継手との距離変化量の考察}

被験者Aの Fig.13 では, 立脚初期の大腿部の内側アーム部と 下腿部の内側アーム部の距離変化量に lateral thrust の影響を確 認した. これはビデオ画像においても一致している. 膝装具の機 能として下腿アーム部の特に内側に関しては, 内反モーメントを 矯正する役割を持っており, 下腿内側の変動幅が約 $15 \mathrm{~mm}$ あるこ とは，その内反に対する反作用として矯正力が効いていると考え られる. Fig.14 に示す被験者Bの下腿部のアーム部の変化量で は, 立脚初期に lateral thrust が出現している. 立脚期でのアーム 部の内側と外側の変位差はあまり見られず追従しているが，立脚 後期の爪先離地から遊脚期にかけて変化量の差が出ている.こ れは膝の内反モーメントの影響により下腿部の内側のアーム部に 力が加わるためで, 逆のその反力で矯正しているものと思われる. これは Fig.13 の大腿部のアーム間距離の変化量でも見られ, 膝 の内反モーメントの影響により内側と外側の差ができると考えられ る. 被験者 C は, ミクリッツ線による内反度合いを計測したところ右 膝 $7.3 \pm 0.2 \mathrm{~mm}$ であり他被験者と比べても内反度合いが小さい. Fig.15 を見ると大腿部と下腿部の外側のアーム部の変化量は小 さく, 大腿部内側アーム部では $5 \mathrm{~mm}$, 下腿部内側アーム部では $7 \mathrm{~mm}$ の変化量であり, 他被験者と比べてと装具の変形が少ないこ とが判る.

以上より, 歩行中の装具の変形量は, 膝の内反度合いと関係し ていると考えられる。

\section{3 継手間を膝装具の装具座標系とした角度変化量の考察}

Fig.16 から Fig.18 は, 歩行中の装具姿勢を装具座標系の X 軸 周り, Y 軸周り, Z軸周りの回転角度の変化量で表している. 今回 使用した実験用装具の剛性を保つ位置が継手部にあり, その継 手の間に装具座標系の原点を配置し, その回転角から歩行の状 態を読み取ることを行った. Fig.16からFig.18の全体的な傾向とし ては, X 軸は立脚支持期においては, 足関節を中心とした装具座 標系原点の回転軌跡を表しており, 遊脚期では股関節を中心とし た装具座標系原点の回転軌跡を表している. Y軸は前額面上で の横方向の振れを表している. Y軸とZ軸に関しては, 角度変化 の変動幅が大きいほど, 膝の内反によって歩容に影響を受けて いると考えられる. 被験者 $\mathrm{A} の$ 装具座標系のY軸周り, Z軸周りの 回転角度の変化量を見ると, 装具装着によって安定した歩容が 実現できていると考えられるが, VASと歩行スピードを見ても疼痛 の有無に関係なく歩行スピードに変化がないので, 基本的な歩容 は安定しているものと思われる. 被験者 $\mathrm{B}$ の立脚期でのX軸周り 回転角度は, 1 歩行周期中の立脚期の割合が他被験者より少な い分, 角度変化量も少ないことが判る. 被験者 C においては, Y 軸の変動幅が小さく, 内反の度合いが小さいよるものと考えられ る.

\section{5. まとめ}

本研究では, 変形性膝関節症のための膝装具 (CBブレース) を用いて, 歩行中の膝装具の構造変化について検証を行った. 上記計測結果に示寸通り, 装具に取り付けた8か所のマーカのみ で膝装具を装着した被験者の歩行の状況を知り得ることができた. 装具構造と歩容とは密接な関係にあり, 装具構造における身体一 の反作用が矯正力となって働くことになる. 今回は, (1)各アーム部 の角度変化 (2)下腿部及び大腿部のアーム部先端と継手との距
離 (3)継手間の中心位置に仮想ポイントを作り, 装具座標系原点 を中心による X 軸周り, Y 軸周り, Z 軸周りの回転角度変化による 装具の姿勢変化 の3つ観点から歩行中の装具構造変形と内反 膝との関係について明らかにすることができた。

今後は, 膝装具の各アーム部の長さや板厚などのパラメータを 変えながら装具の構造と歩容との関係をより明らかにすると共に, 装具の矯正力は, 下腿部の内側に掛けることが重要であると言わ れていることに対して, 専用の計測用装具を開発し, この点につ いても明らかにしたいと考えている.

\section{謝 辞}

本研究は, 平成 27 年度公益財団法人精密測定技術振興財団 の研究助成を受けて行われました. 感謝申し上げます.

\section{参考文献}

1) 日本整形外科学会,変形性膝関節症.整形外科シリーズ3 2010.

2) JH. Kellgren, JS. Lawrence, Radiological Assessment of Osteo-Arthrosis. Annals of the Rheumatic Diseases 1957; 16(4): 494-502.

3) 厚生労働省，平成 26 年度患者調査 閲覧年次 2014, 第 95 表 総患者数,性·年齢階級 $\times$ 疾病中分類別.

4) 吉村典子, 変形性関節症の疫学研究〜大規模コホート研 究 ROAD より〜, CLINICAL CALCIUM 2009;19(11): 20-25.

5) 古賀良生, 変形性関節症 病態と保存療法. 南江堂 2008 .

6) 飯田智絵, 櫻井愛子, 井川達也, 長嶋正樹, 福井康之, 山 本澄子, 変形性膝関節症患者の歩行分析, 第 50 回日本理 学療法学術大会, 2015.

7) 田中真一他, 外来通院している变形性膝関節症患者の歩 行分析, West Kyushu Journal of Rehabilitation Science 2012; 55-57.

8) A.Chang, et al., Thrust during ambulation and the progression of knee osteoarthritis, Arthritis Rheum 2004; 50(12) : 3897-3903.

9) GH. Lo, WF. Harvey, TE. McAlindon, Associations of Varus Thrust and Alignment with Pain in Knee Osteoarthritis",Arthritis Rheum 2012; 64(7): 2252-2259.

10) Y.Kuroyanagi, et al., A quantitative assessment of various thrust in patients with medial knee osteoarthritis, The knee 2012; 19(2): 130-134.

11）清水新悟, 佐橋政次, 清田信幸, 徳田康彦, 山岸慶子, 変 形膝関節症の足底板療法の評価, 日本義肢装具学会誌 2006; 22(1): 32-42.

12）小村孝，津村暢宏，黒坂昌弘，内側型変形性膝関節症患 者の歩行分析に関寸る研究, 神戸大学医学部紀要 2001; 61(4), 89-94.

13）岡本卓也, 浅枝諒, 寺井千晶, 河野愛史, 島田昇, 出家正 隆, 軟性装具の変形性膝関節症患者の歩行時 Lateral thrust に対する効果, 第 49 回日本理学療法学術大会 2014.

14) TD.Cooke, EA.Sled, RA.Scudamore, Frontal plane knee alignment: a call for standardized measurement, The Journal of Rheumatology 2007; 34: 1796-1801.

15) M.Akai, et al., Development of new disease-specific QOL measure for patients with knee osteoarthritis, Japanese Knee Osteoarthritis Measure (JKOM), The Journal of the Japanese Orthopaedic Association 2006; 80(5): 307-315. 